\title{
Hypofractionated and hyper-hypofractionated radiation therapy in postoperative breast cancer treatment
}

\author{
Marcel Fang ${ }^{1}$ \\ (iD) Gustavo Nader Marta 2,3
}

\begin{abstract}
1. Departamento de Rádio-Oncologia, PreventSenior, São Paulo, SP, Brasil 2. Department of Radiology and Oncology, Division of Radiation Oncology, Instituto do Câncer do stado de São Paulo (Icesp), Faculdade de Medicina da Universidade de São Paulo, São Paulo, SP, Brasil 3. Departamento de Rádio-Oncologia, Hospital Sírio-Libanês, São Paulo, SP, Brasil
\end{abstract}

\section{SUMMARY}

INTRODUCTION: Radiation therapy is widely used as adjuvant treatment in breast cancer patients. In the last decades, several studies have been designed to evaluate the safety and efficacy of hypofractionated breast radiation therapy. More recently, even shorter regimens with doses above $4 \mathrm{~Gy}$ (hyper-hypofractionation) have also been proposed. This study aims to present a narrative review of the various hypofractionation protocols used to treat breast cancer patients with a focus on clinical application.

RESULTS: Long-term results from several phase III randomized controlled trials demonstrated the safety and efficacy of hypofractionated breast radiation therapy using 15 or 16 fractions for early and locally advanced disease. The results of the initial clinical trials of hyper-hypofractionation are also encouraging and it is believed that these regimens may become routine in the indication of adjuvant radiation therapy treatment after the ongoing studies on this subject have matured.

CONCLUSIONS: The idea that normal tissues could present high toxicity at doses above 2 Gy was opposed by clinical trials that demonstrated that moderate hypofractionation had similar results regarding oncological and cosmetic outcomes compared to conventional fractionation. Cosmetic and toxicity results from hyper-fractionation studies are in principle favorable. However, the long-term oncological results of studies that used hyper-hypofractionation for the treatment of breast cancer patients are still awaited.

KEYWORDS: Radiation therapy. Breast neoplasms. Radiation dose hypofractionation.

\section{INTRODUCTION}

Radiation therapy (RT) is one of the main modalities for adjuvant treatment of breast cancer, performed in approximately $87 \%$ of the cases since it brings positive results in local control and overall survival in patients with early and locally advanced disease ${ }^{1.2}$.

The most used standard dose of RT for decades was $50 \mathrm{~Gy} / 50.4 \mathrm{~Gy}$, prescribed in 25-28 sessions of
1.8-2 Gy daily, i.e., conventional fractionation (CF). This scheme was based on the assumption that daily doses above 2 Gy could increase the side effects of the treatment ${ }^{3}$. However, in recent decades several studies were designed to evaluate the safety and efficacy of hypofractionated radiation therapy for breast cancer. The objective of the present study is to present a

DATE OF SUBMISSION: 26-Mar-2020

DATE OF ACCEPTANCE: 21-Apr-2020

CORRESPONDING AUTHOR: Marcel Fang

Avenida Angelica 1045

Sao Paulo, SP - Brasil - 04547-100 - Tel.:+55 1121780010

E-mail: marcelfang@gmail.com 
narrative review of the several protocols for hypofractionated radiation therapy for the treatment of breast cancer, with a focus on clinical application.

\section{MODERATE HYPOFRACTIONATION- RANDOMIZED CLINICAL TRIALS}

A Canadian study randomized 1,234 women diagnosed with early-stage cancer submitted to breast-conserving surgery to receive 42.5 Gy in 16 fractions, or $50 \mathrm{~Gy}$ in 25 fractions ${ }^{4}$. The risk of local recurrence in ten years was $6.7 \%$ for the standard irradiation in comparison with $6.2 \%$ among the 622 who received hypofractionation. After ten years, $71.3 \%$ of the women in the control group, in comparison with $69.8 \%$ of the women in the hypofractionated group, had a good or excellent cosmetic result ${ }^{5}$.

A pilot study conducted in UK randomized 1,410 patients between 1986 and 1998 after conservative breast surgery into three groups: a control group with a dose of 50 Gy in 25 sessions of 2 Gy daily, and two other groups with schemes hypofractionated into 13 sessions: 39 Gy in 13 sessions of 3.0 Gy daily, and 42.9 Gy with 3.3 Gy daily. The primary outcome of this study was the late effect in normal tissue, and the secondary outcome was local control. After a minimum follow-up period of five years, the risk of emergence of any changes in the appearance of the breast after $50 \mathrm{~Gy}, 39 \mathrm{~Gy}$, and $42.9 \mathrm{~Gy}$ was $39.6 \%, 30.3 \%$, and $45.7 \%$, respectively. Ipsilateral tumor recurrence in the tested fractionations was similar to the conventional fractionation of $50 \mathrm{~Gy}^{6}$. After ten years of follow-up, the risk of ipsilateral recurrence was $12.1 \%$ (95\% CI 8.8 - 15.5) in the 50 Gy group, $14.8 \%(11.2$ - 18.3) in the

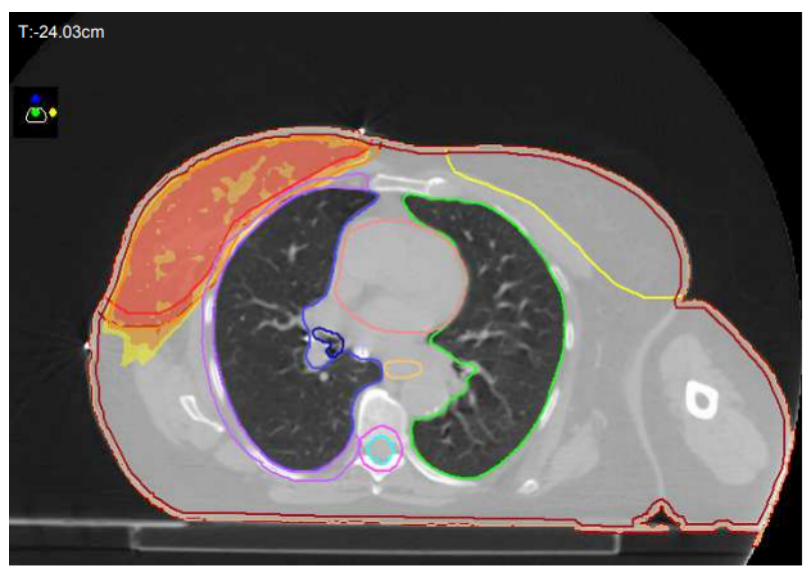

FIGURE 1. TOMOGRAPHIC PLANE WITH ISODOSE CURVES FOR HYPER-HYPOFRACTIONATION PLANNING.
39 Gy group, and $9.6 \%$ (6.7 - 12.6) in the 42.9 Gy group, respectively. Based on the pilot study described previously, two randomized clinical trials were developed in parallel by the UK group: Start A and Start B. The first virtually kept the design of the pilot study, only correcting the dose of one of the groups to $41.6 \mathrm{~Gy}$ into 13 sessions of $3.2 \mathrm{~Gy}^{7}$. Whereas Start B randomized the patients into two groups: a control group with the standart fraction, 50 Gy into 25 fractions of 2 Gy daily, and a second group with fractionation of 15 sessions of $2.67 \mathrm{~Gy}$ daily $^{8}$. In total, 1,105 women were assigned to the 50 Gy group, and 1,110 to the 40 Gy group. After a mean follow-up of six years (IQR 5.0 - 6.2), the locoregional recurrence rate in five years was $2.2 \%(95 \% \mathrm{CI}$ 1.3 to 3.1 ) in the 40 Gy group, and 3.3\% (95\% CI 2.2 to 4.5 ) in the 50 Gy group, representing an absolute difference of $0.7 \%$ (95\% CI -1\% to 0.9\%). Photographic and patients' self-assessments showed lower rates of late adverse events after 40 Gy than after 50 Gy. The update of the UK studies proved the effectiveness and safety of the hypofractionated treatment with a long follow-up period 9 .

Wang et al. ${ }^{10}$ randomized women (cT3-cT4 or with at least four compromised lymph nodes), post-mastectomy to receive 50 Gy into 25 fractions $(n=414)$, or 43.5 Gy into 15 fractions $(n=406)$ in the chest wall and lymphatic drainage. The cumulative incidence in five years of locoregional recurrence was 8.3\% (95\% CI 5.8 to 10.7) in the hypofractionated RT group, and $8.1 \%$ (90\% CI 5.4 to 10.6) in the of conventional fractionation group (absolute difference of $0 \%$ to $2 \%$, 90\% CI -3.0 to 2.6 ; hazard ratio $1.10,90 \%$ CI 0.72 to $1.69 ; \mathrm{p}<0.0001$ for noninferiority). There were no significant differences between the groups regarding

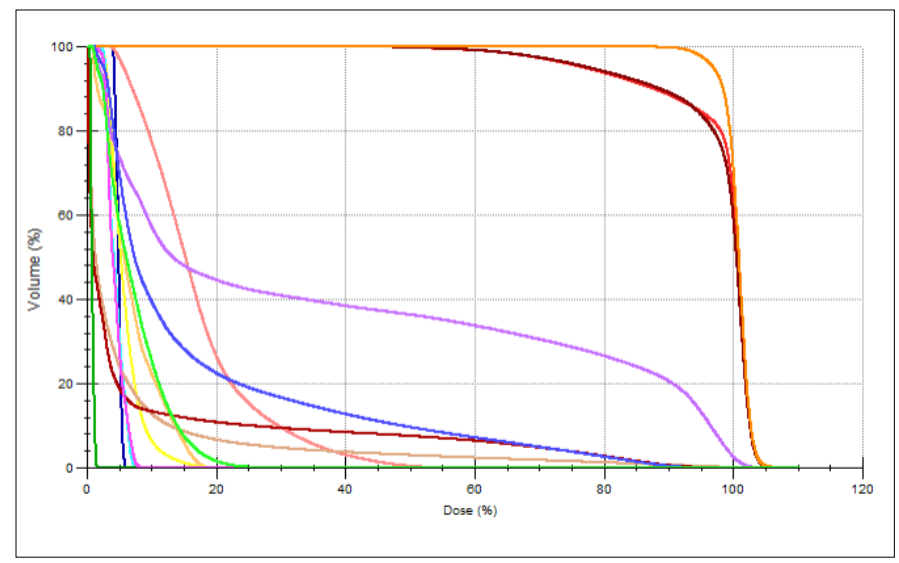

FIGURE 2. DOSE HISTOGRAM X HYPER-

HYPOFRACTIONATED TREATMENT PLAN VOLUME. 
acute and late toxicities, except for grade 3 acute skin toxicity, which was higher in the RT group with conventional fractionation (14 [3\%] HF-M versus 32 [8\%] CF; $p<0.0001)$. There was no significant difference in the overall survival or disease-free survival between the groups.

Although some countries and specialized centers use routine moderate hypofractionated RT for the treatment of all breast cancer patients, regardless of the staging and type of surgery performed, this recommendation is not employed by many in clinical practice, particularly in patients with advanced disease who require wider radiation fields involving the lymphatic drainage ${ }^{11}$.

Table 1 summarizes the various treatment regimens employed in randomized clinical trials published on moderate hypofractionated RT.

\section{HYPER-HYPOFRACTIONATION- RETROSPECTIVE AND PROSPECTIVE STUDIES}

Currently, with the advance in RT treatment techniques, fractionations with high daily doses (hyper-hypofractionation) and fewer days of treatment have been used in some new clinical trials. However, these fractionations have been the object of studies for over 30 years, mainly in elderly patients, since this population presents greater difficulty in treatment adherence due to multiple comorbidities ${ }^{12-16}$.

In a pioneer publication in 1987 by Roston et al. ${ }^{17}, 84$ elderly patients with breast carcinoma were treated with once-a-week regimens using 6.5 Gy in a total of six fractions. The mean age of the patients

TABLE 1. PROSPECTIVE STUDIES ON MODERATE HYPOFRACTIONATED RADIATION THERAPY

\begin{tabular}{l|l|l} 
Study & N & FRACTIONATION \\
\hline $\begin{array}{l}\text { Whelan et } \\
\text { al., 2002 }\end{array}$ & 1,234 & $\begin{array}{l}50 \text { Gy - 2 Gy/fraction, 35 days, } \\
\text { versus } \\
42.5 \text { Gy - 2.65 Gy/fraction, 22 days }\end{array}$ \\
\hline $\begin{array}{l}\text { Yarnold et } \\
\text { al., 20056 }\end{array}$ & 1,410 & $\begin{array}{l}50 \text { Gy into 25 fractions; 39 Gy into 13 frac- } \\
\text { tions, } \\
\text { or } \\
42.9 \text { Gy into 3.3 Gy/fraction }\end{array}$ \\
\hline $\begin{array}{l}\text { Haviland et } \\
\text { al., 20139 }\end{array}$ & 2,236 & $\begin{array}{l}\text { Start A: 50 Gy; 2 Gy fractions versus 41.6 Gy } \\
\text { into 13 fractions 3.2 Gy }\end{array}$ \\
\hline $\begin{array}{l}\text { Wang et al., } \\
\text { 201910 }\end{array}$ & 820 & $\begin{array}{l}\text { Start B0 Gy into 25 fractions; versus 40 Gy } \\
\text { into 15 fractions, } 25 \text { Gy/fractions } \\
\text { versus } \\
43.5 \text { Gy into 15 Gy/fractions } \\
\text { Note: Post-mastectomy. }\end{array}$ \\
\hline
\end{tabular}

was 69.2 years. The treatment was well tolerated by all patients, and the initial results of local control were encouraging.

During the same period, between 1987 and 1999, 150 patients with a median age of 78 years who had non-metastatic breast tumors were treated with surgery and then hyper-hypofractionated adjuvant RT. Radiation therapy was performed once a week, in five fractions of $6.5 \mathrm{~Gy}$, to a total dose of $32.5 \mathrm{~Gy}$ (boost dose to the tumor bed in $33 \%$ ). The acute toxicity of all degrees totaled $26.5 \%$, and the rate of all late reactions was $45.5 \%$, in most cases grade I and grade II. The rate of local recurrence in the long term was $2.3 \%$ and disease-free survival at five and ten years was $80 \%$ and $71.5 \%$, respectively ${ }^{18}$.

In a retrospective series, Kirova et al. ${ }^{19}$ concluded that the hyper-hypofractionated treatment is an acceptable alternative. Three hundred and sixty-seven women aged 70 years or more, with clinical stages I or II, treated with conservative breast surgery and adjuvant RT at the Institut Curie received a schedule for normofractionated radiation therapy (50 Gy into 25 fractions with or without a boost dose at the tumor bed) or a hyper-hypofractionated scheme (32.5 Gy into five fractions of $6.5 \mathrm{~Gy}$, once a week). A total of 317 patients were on the normofractionated group, and 50 were in the hyper-hypofractionated group. The survival rates were similar between the two groups (93\% and 91\% for locoregional-recurrence-free survival, and $92 \%$ and $93 \%$ for metastasis-free survival, respectively).

Monten et al. ${ }^{20}$ published, in 2017, a phase II study that investigated the feasibility and safety of the hyper-hypofractionated treatment in women over 65 years with five fractions of doses between $5.7 \mathrm{~Gy}$ and 6.5 Gy daily. Clinically relevant dermatitis was observed in $11.6 \%$ of the patients and occurred only in the boost dose subgrup (17.5\% grade $2-3$ versus $0 \%$ in the group without boost dose). The authors concluded that the treatment is technically feasible and resulted in low acute toxicity.

Dragun et al. ${ }^{21}$ published the first results of a prospective phase II trial. Patients who underwent conservative breast surgery in stages 0 , I, or II with negative surgical margins received radiation therapy for 30 or $28.5 \mathrm{~Gy}$ into five once-weekly fractions with or without a boost dose at the tumor bed. One hundred and fifty-eight eligible patients were submitted to whole-breast hyper-hypofractionated RT once-weekly. Disease-free survival after three years and the overall 
TABLE 2. AVAILABLE STUDIES ON HYPER-HYPOFRACTIONATION.

\begin{tabular}{|c|c|c|c|c|}
\hline Study & $\begin{array}{l}\text { TYPE OF } \\
\text { STUDY }\end{array}$ & $\mathrm{N}$ & FRACTIONATION & Note \\
\hline Rostom et al., $1987^{17}$ & Retrospective & 84 & 6.5 Gy x 6 fractions & Weekly \\
\hline Ortholan et al., $2005^{18}$ & $\begin{array}{l}\text { Prospective sin- } \\
\text { gle-arm study }\end{array}$ & 150 & $\begin{array}{l}6.5 \text { Gy } \times 5 \text { fractions; FSC } 5.5 \text { Gy } \times 5 \\
\text { fractions }\end{array}$ & $\begin{array}{l}\text { Weekly } \\
\text { Supplementation of dose } 6.5 \text { Gy } \times 1 \\
\text { or } 2 \text { fractions }\end{array}$ \\
\hline Kirova et al., $2009^{19}$ & Retrospective & 367 & $\begin{array}{l}50 \text { Gy x } 25 \text { fractions } \\
32.5 \text { Gy } \times 5 \text { fractions x } 6.5 \text { Gy }\end{array}$ & $\begin{array}{l}\text { Weekly } \\
\text { N(50 Gy) } 317 \text { × (32.5 Gy) } 50\end{array}$ \\
\hline Monten et al., $2017^{20}$ & $\begin{array}{l}\text { Prospective } \\
\text { phases I and II }\end{array}$ & 95 & $\begin{array}{l}28.5 \text { Gy to } 5.7 \text { Gy breast or chest wall; } \\
27 \text { Gy/5.4 Gy FSC; } \\
32.5 \text { Gy/6.5 Gy to } 34.5 \text { Gy/6.9 Gy SIB at } \\
\text { the tumor bed }\end{array}$ & $\begin{array}{l}\text { Alternate days } \\
\text { SIB associated with higher toxicity }\end{array}$ \\
\hline Dragun et al., $2017^{\mathbf{2 1}}$ & $\begin{array}{l}\text { Prospective sin- } \\
\text { gle-arm study }\end{array}$ & 41 & 6 Gy $\times 5$ fractions & SIB with more toxicity \\
\hline Rebouças et al., $2019^{22}$ & $\begin{array}{l}\text { Prospective } \\
\text { single-arm stage } \\
\text { Il study }\end{array}$ & 44 & 30 Gy x 5 fractions of 6.0 Gy & $\begin{array}{l}\text { Weekly } \\
\text { Preliminary results }\end{array}$ \\
\hline Agrawal et al., $2011^{24}$ & $\begin{array}{l}\text { Prospective } \\
\text { randomized }\end{array}$ & 915 & $\begin{array}{l}40 \text { Gy into } 15 \text { fractions (control), } 28.5 \text { Gy } \\
\text { into } 5.7 \text { Gy, or } 30 \text { Gy ( } 6 \text { Gy x } 51 \text { x weekly) }\end{array}$ & Weekly \\
\hline
\end{tabular}

$\mathrm{SIB}=$ Simultaneous Integrated Boost.

survival rates were $97.5 \%$ and $96.2 \%$, respectively. The most commonly observed acute toxicities of grade 1 or 2 were chest pain, radiodermatitis, and fatigue. Excellent or good cosmesis was $82.3 \%$, and $17.7 \%$ was average or poor.

Rebouças et al. ${ }^{22}$ presented the initial results of toxicities for a prospective phase II study. The prescribed dose was $30 \mathrm{~Gy}$ into five fractions of $6.0 \mathrm{~Gy}$, one fraction weekly, without a supplementary dose at the tumor bed. Skin erythema was the most common acute adverse event observed. At the end of the treatment, 30 patients $(68.2 \%)$ presented some degree of dermatitis due to radiation. Regarding the cosmetic appearance, there was no significant difference between the pre-treatment and one-year assessment. The overall survival after two years and disease-free survival were, respectively, $96.8 \%$ and $97.7 \%$.

In an UK phase III multicenter, randomized trial (Fast-Forward), the participants were randomized into three different groups: 40 Gy into 15 fractions (control), 28.5 Gy into five fractions, and $30 \mathrm{~Gy}$ into five fractions. Grade 3 RTOG toxicities were: 40 Gy 6/44 (13.6\%); 27 Gy 5/51 (9.8\%); 26 Gy 3/52 (5.8\%). There were no toxicities grade 4 or 5 . The patients with grade 3 CTCAE toxicity were: 40 Gy $0 / 43 ; 27$ Gy $1 / 41$ (2.4\%); and $26 \mathrm{~Gy} 0 / 53$. In conclusion, the acute skin toxicity in patients enrolled in the Fast-forward study was acceptable. However, for this hyper-hypofractionation scheme to be used in clinical practice, the formal publication of the study with long-term clinical follow-up is expected ${ }^{23}$.

Table 2 summarizes the various treatment regimens employed in the retrospective and prospective studies published on hyper-hypofractionated RT.

\section{IMPLICATIONS FOR CLINICAL PRACTICE}

Adjuvant RT after breast surgery carried out in five to seven weeks was, for decades, the gold standard in the treatment of early breast cancer with widely recognized oncologic and cosmetic results. The idea that normal tissues could present high toxicity with doses above $2 \mathrm{~Gy}$ and, consequently, the fear of radio-oncologists in using shorter treatment regimens was pioneeringly countered by the Canadian OCOG $^{4}$ study and the British Studies ${ }^{7.8}$. The long follow-up results of these studies have proven that the moderate hypofractionated treatment showed similar results regarding oncologic and cosmetic outcomes and quality of life when compared to conventional fractionation. These results also encouraged the change of the understanding of ASTRO, in $2018^{25}$, in comparison to the previous understanding of $2011^{26}$, making it possible to use the moderate hypofractionated regimen more widely in the early stages.

The Chinese phase III randomized trial with more 
than 800 patients ${ }^{10}$, despite its limitations, evaluated the use of moderate hypofractionation post-mastectomy in the chest wall and lymphatic drainage, paving the way for the use of this treatment regimen in patients with more advanced disease staging. In addition, the analysis of the subgroup of patients who received irradiation of the lymph node chain, as well as post-mastectomy in British studies ${ }^{6-8}$, also did not demonstrate worse results in these patients in relation to rates of local control, survival, and side effects.

The evolution in the concepts of radiobiology and, in particular, the evolution in the delivery of radiation over the last two decades has allowed healthy tissues to be increasingly spared from doses and, consequently, paved the way for studies with even shorter schemes of RT, i.e., hyper-hypofractionation with doses above $4 \mathrm{~Gy}$. The cosmetic and toxicity results of hyper-hypofractionation studies have been, in principle, favorable ${ }^{20.24}$. However, we still wait for the long-term oncological results of patients treated with hyper-hypofractionation schemes for its application in clinical practice.

\section{FINAL CONSIDERATIONS}

Moderate hypofractionated RT schemes for adjuvant treatment of breast cancer have become a real option in recent years. The worries regarding acute and late toxicities, as well as regarding the oncologic control, are no longer reasons for not indicating moderate hypofractionated RT. Despite this, there is still a reluctance to employ this scheme without restrictions in clinical practice, mainly in patients who underwent a mastectomy, who need to receive treatment of the regional lymph node chains, and who were submitted to surgical reconstruction.

Hyper-hypofractionation is being studied and, apparently, shows encouraging results. It is believed that, in the future, such schemes may become routine in the indication of adjuvant treatment with RT for locally advanced early tumors. More prospective randomized studies are needed to prove the efficacy and safety of hyper-hypofractionation.

\section{Author's Contribution}

All authors contributed equally to this work.

\section{RESUMO}

INTRODUÇÃO: A radioterapia é amplamente utilizada como tratamento adjuvante nas pacientes com câncer de mama. Nas últimas décadas, diversos estudos foram desenhados para avaliar a segurança e a eficácia da radioterapia hipofracionada moderada de mama. Mais recentemente, esquemas ainda mais curtos, com doses acima de $4 \mathrm{~Gy}$ (hiper-hipofracionamento), foram também propostos. Este estudo tem o objetivo de apresentar uma revisão narrativa dos diversos protocolos de hipofracionamento utilizados no tratamento do câncer de mama com o foco na aplicação clínica.

RESULTADOS: Os resultados de longo prazo de diversos ensaios clínicos randomizados fase III demonstraram a segurança e a eficácia da radioterapia hipofracionada moderada utilizando 15 ou 16 frações para doença inicial e localmente avançada. Os resultados dos ensaios clínicos iniciais de hiper-hipofracionamento são também animadores e acredita-se que esses esquemas poderão se tornar rotina na indicação do tratamento adjuvante com radioterapia após a maturação dos estudos em andamento sobre esse tema.

CONCLUSÕES: A ideia de que os tecidos normais poderiam apresentar toxicidade elevada com doses acima de 2 Gy foi pioneiramente contraposta por ensaios clínicos que comprovaram que o hipofracionado moderado apresentava resultados semelhantes em relação aos desfechos oncológicos e cosméticos quando comparados ao fracionamento convencional. Os resultados cosméticos e de toxicidade dos estudos de hiper-hipofracionamento são, em princípio, favoráveis. Todavia, ainda se aguardam os resultados oncológicos de longo prazo dos estudos que aplicaram o hiper-hipofracionamento para o tratamento das pacientes com câncer de mama.

PALAVRAS-CHAVE: Radioterapia. Neoplasias da mama. Hipofracionamento da dose de radiação.

\section{REFERENCES}

1. Early Breast Cancer Trialists' Collaborative Group (EBCTCG), Darby S, McGale P, Correa C, Taylor C, Arriagada R, Clarke M, et al. Effect of radiotherapy after breast-conserving surgery on 10-year recurrence and 15 -year breast cancer death: meta-analysis of individual patient data for 10,801 women in 17 randomised trials. Lancet. 2011;378(9804):1707-16.

2. Early Breast Cancer Trialists' Collaborative Group (EBCTCG), McGale P, Taylor C, Correa C, Cutter D, Duane F, Ewertz M, et al. Effect of radiotherapy after mastectomy and axillary surgery on 10-year recurrence and 20-year breast cancer mortality: meta-analysis of individual patient data for 8135 women in 22 randomised trials. Lancet. 2014;383(9935):2127-35.
3. Halperin EC, Wazer DE, Perez CA, Brady LW. Perez \& Brady's principles and practice of radiation oncology. $7^{\text {th }}$ ed. Philadelphia: Wolters Kluwer; 2018.

4. Whelan T, MacKenzie R, Julian J, Levine M, Shelley W, Grimard L, et al. Randomized trial of breast irradiation schedules after lumpectomy for women with lymph node-negative breast cancer. J Natl Cancer Inst. 2002;94(15):1143-50.

5. Whelan TJ, Pignol JP, Levine MN, Julian JA, MacKenzie R, Parpia S, et al. Long-term results of hypofractionated radiation therapy for breast cancer. N Engl J Med. 2010;362(6):513-20. 
6. Yarnold |, Ashton A, Bliss |, Homewood |, Harper C, Hanson |, et al. Fractionation sensitivity and dose response of late adverse effects in the breast after radiotherapy for early breast cancer: long-term results of a randomised trial. Radiother Oncol. 2005;75(1):9-17.

7. START Trialists' Group, Bentzen SM, Agrawal RK, Aird EG, Barrett |M, Barrett-Lee PJ, Barrett-Lee PJ, et al. The UK Standardisation of Breast Radiotherapy (START) Trial A of radiotherapy hypofractionation for treatment of early breast cancer: a randomised trial. Lancet Oncol. 2008;9(4):331-41.

8. START Trialists' Group, Bentzen SM, Agrawal RK, Aird EG, Barrett IM, Barrett-Lee PJ, Bentzen SM, et al. The UK Standardisation of Breast Radiotherapy (START) Trial B of radiotherapy hypofractionation for treatment of early breast cancer: a randomised trial. Lancet. 2008;371(9618):1098-107.

9. Haviland IS, Owen IR, Dewar IA, Agrawal RK, Barrett I, Barrett-Lee PI, et al; START Trialists' Group. The UK Standardisation of Breast Radiotherapy (START) trials of radiotherapy hypofractionation for treatment of early breast cancer: 10-year follow-up results of two randomised controlled trials. Lancet Oncol. 2013;14(11):1086-94.

10. Wang SL, Fang H, Song YW, Wang WH, Hu C, Liu YP, et al. Hypofractionated versus conventional fractionated postmastectomy radiotherapy for patients with high-risk breast cancer: a randomised, non-inferiority, open-label, phase 3 trial. Lancet Oncol. 2019;20(3):352-60.

11. Marta GN, Poortmans P. Moderately hypofractionated breast radiation therapy: is more evidence needed? Lancet Oncol. 2019;20(5):e226.

12. Truong PT, Bernstein V, Lesperance M, Speers CH, Olivotto IA. Radiotherapy omission after breast-conserving surgery is associated with reduced breast cancer-specific survival in elderly women with breast cancer. Am J Surg. 2006;191(6):749-55.

13. Hancke K, Denkinger MD, König J, Kurzeder C, Wöckel A, Herr D, et al. Standard treatment of female patients with breast cancer decreases substantially for women aged 70 years and older: a German clinical cohort study. Ann Oncol. 2010;21(4):748-53.

14. Weiss A, Noorbakhsh A, Tokin C, Chang D, Blair SL. Hormone receptor-negative breast cancer: undertreatment of patients over 80. Ann Surg Oncol. 2013;20(10):3274-8

15. Enger SM, Thwin SS, Buist DS, Field T, Frost F, Geiger AM, et al. Breast cancer treatment of older women in integrated health care settings. I Clin Oncol. 2006;24(27):4377-83.

16. Biganzoli L, Wildiers H, Oakman C, Marotti L, Loibl S, Kunkler I, et al. Management of elderly patients with breast cancer: updated recommendations of the International Society of Geriatric Oncology (SIOG) and
European Society of Breast Cancer Specialists (EUSOMA). Lancet Oncol. 2012;13(4):e148-60.

17. Rostom AY, Pradhan DG, White WF. Once weekly irradiation in breast cancer. Int J Radiat Oncol Biol Phys. 1987;13(4):551-5.

18. Ortholan C, Hannoun-Lévi JM, Ferrero JM, Largillier R, Courdi A. Long-term results of adjuvant hypofractionated radiotherapy for breast cancer in elderly patients. Int J Radiat Oncol Biol Phys. 2005;61(1):154-62.

19. Kirova YM, Campana F, Savignoni A, Laki F, Muresan M, Dendale R, et al; Institut Curie Breast Cancer Study Group. Breast-conserving treatment in the elderly: long-term results of adjuvant hypofractionated and normofractionated radiotherapy. Int | Radiat Oncol Biol Phys. 2009;75(1):76-81.

20. Monten C, Lievens Y, Olteanu LAM, Paelinck L, Speleers B, Deseyne P, et al. Highly accelerated irradiation in 5 fractions ( $\mathrm{HAl}-5)$ : feasibility in elderly women with early or locally advanced breast cancer. Int | Radiat Oncol Biol Phys. 2017:98(4):922-30

21. Dragun AE, Ajkay NJ, Riley EC, Roberts TL, Pan J, Rai SN, et al. First results of a phase 2 trial of once-weekly hypofractionated breast irradiation (WHBI) for early-stage breast cancer. Int | Radiat Oncol Biol Phys. 2017;98(3):595-602.

22. Rebouças LM, Campos CS, D'Amico GM, Lustosa AB, Fregnani JH. Onceweekly hypofractionated radiotherapy for breast cancer: first results of a phase II clinical trial. Breast J. 2019;25(5):953-7.

23. Brunt AM, Wheatley D, Yarnold I, Somaiah N, Kelly S, Harnett A, et al; FAST-Forward Trial Management Group. Acute skin toxicity associated with a 1-week schedule of whole breast radiotherapy compared with a standard 3-week regimen delivered in the UK FAST-Forward Trial. Radiother Oncol. 2016;120(1):114-8

24. FAST Trialists group, Agrawal RK, Alhasso A, Barrett-Lee PI, Bliss IM, Bliss P, Bloomfield D, et al. First results of the randomised UK FAST Trial of radiotherapy hypofractionation for treatment of early breast cancer (CRUKE/04/015). Radiother Oncol. 2011;100(1):93-100.

25. Smith BD, Bellon IR, Blitzblau R, Freedman G, Haffty B, Hahn C, et al. Radiation therapy for the whole breast: executive summary of an American Society for Radiation Oncology (ASTRO) evidence-based guideline. Pract Radiat Oncol. 2018;8(3):145-52.

26. Smith $B D$, Bentzen $S M$, Correa $C R$, Hahn CA, Hardenbergh $\mathrm{PH}$, Ibbott GS, et al. Fractionation for whole breast irradiation: an American Society for Radiation Oncology (ASTRO) evidence-based guideline. Int | Radiat Oncol Biol Phys. 2011;81(1):59-68. 